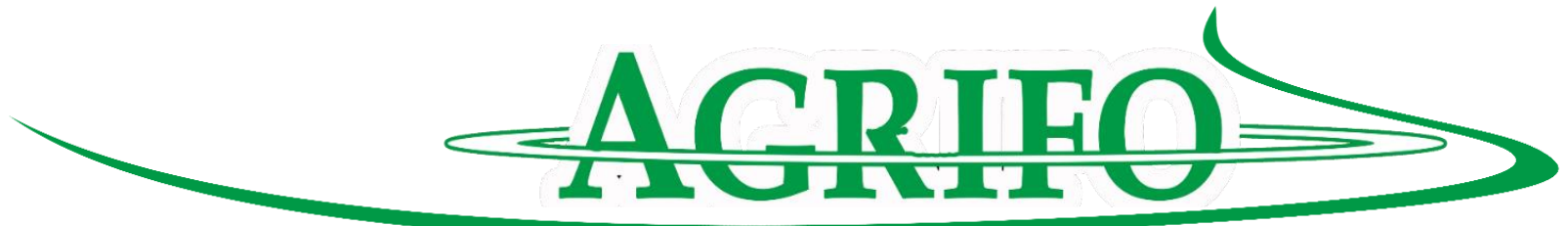

\title{
HUBUNGAN LUAS LAHAN DAN TINGKAT PENDIDIKAN DENGAN PENINGKATAN PENDAPATAN USAHATANI PADI DI DESA TOPORE KECAMATAN PAPALANG
}

\author{
Sulaiman', Rasmahwati ${ }^{2}$ \\ Corresponding Author : sulaiman_teddu@yahoo.co.id
}

\begin{abstract}
This research intent for example to : 1) Knowing relationship among farm extent with paddy farming revenue enhancement, and 2) Knowing relationship among level education with paddy farming revenue enhancement. Meanwhile this research utility is 1) As material as information for farmer deeping to bring off paddy farming, 2) Can be consideration divide policy take in arrange program that concern farmer revenue enhancement effort, and 3) Literature material for further researcher. This research was performed at Topore Village Papalang district Mamuju Regency, on august until September 2017. Topore silvan elect as region of research at goes upon on that judgment Topore Village constitutes one of village which have acreage of rice filed extent that enough extensive. Population in observational is all paddy farmer that gets location at Silvan Topore Papalang district Mamuju Regency. Meanwhile sample in observational it is chosen at Simple Random Sampling with farmer amount as much 432 person taken by respondents as big as 10 percents which is as much 43 respondents. Result observationaling to point out that : Far ranging ala ascendant farm signifikan to paddy farming revenue enhancement which is as big as 84,7 percents, meanwhile Zoom education not signifikan's ala ascendant to paddy farming revenue enhancement which is just as big as 0,7 percents.
\end{abstract}

Keywords : among farm, revenue, and paddy

\section{PENDAHULUAN}

Pertanian adalah proses menghasilkan bahan pangan, ternak, serta produk-produk agroindustri dengan cara memanfaatkan sumber daya tumbuhan dan hewan. Pemanfaatan sumber daya ini terutama berarti budi daya (bahasa Inggris: cultivation, atau untuk ternak: raising). Namun demikian, pada sejumlah kasus yang sering dianggap bagian dari pertanian dapat berarti ekstraksi semata, seperti penangkapan ikan atau eksploitasi hutan (bukan agroforestri).
Pertanian (agriculture) bukan hanya merupakan aktivitas ekonomi untuk menghasilkan pendapatan bagi petani saja (Elizabeth, 2016). Lebih dari itu, pertanian/agrikultur adalah sebuah cara hidup (way of life atau livehood) bagi sebagian besar petani di Indonesia. Oleh karena itu pembahasan mengenai sektor dan sistem pertanian harus menempatkan subjek petani, sebagai pelaku sektor pertanian secara utuh, tidak saja petani sebagai homo economicus, melainkan juga sebagai homo socius dan homo religius. Konsekuensi pandangan ini adalah dikaitkannya unsur-unsur nilai sosial-

\footnotetext{
${ }^{1}$ Staff DPK Universitas Tomakaka Mamuju dan Mahasiswa Pascasarjana Universitas Hasanuddin Makassar

2 Penyuluh Pertanian Lapangan di Kantor Dinas Tanaman Pangan, Hortikultura dan Peternakan Kabupaten Mamuju
} 
budaya lokal, yang memuat aturan dan pola hubungan sosial, politik, ekonomi, dan budaya ke dalam kerangka paradigma pembangunan sistem pertanian.

Di sisi lain sektor pertanian sangat urgen perannya dalam kehidupan manusia, seperti bahan pangan. Pangan merupakan komoditas yang sangat strategis, karena selain untuk memenuhi kebutuhan pokok, disisi lain pangan juga dapat mempengaruhi stabilitas suatu bangsa. Apabila hal ini dilakukan oleh massa, maka dapat mengarah pada bentuk-bentuk ancaman bagi stabilitas dan ketahanan nasional suatu bangsa. Sehingga bahan pangan ini dapat dikatakan strategis dari segi ekonomi, budaya, dan politik (Arsyad, 2014).

Hal ini cukup rasional karena berdasarkan pendapat Rosegrant, et all (1987), bahwa tingkat partisipasi konsumsi beras dari penduduk di Indonesia adalah $90 \%$, berarti $90 \%$ dari penduduk Indonesia mengkonsumsi beras sebagai bahan pangan pokok. Peranan beras dinilai masih cukup penting, karena di samping partisipasinya dalam konsumsi pangan sangat besar, pasokan (suplay) dari produksi dalam negeri tidak merata, dan volume perdagangan beras dunia (sebagai sumber pasokan alternatif) relatif sangat kecil dan tidak dapat diandalkan, juga karena " fanatisme " rakyat Indonesia terhadap beras sangat tinggi, sehingga beras memiliki nilai politis dan nilai strategis.

Di sisi lain, Indonesia sebagai Negara yang memiliki potensi sumber daya alam. Meskipun sampai sekarang potensi tersebut belum dapat dikelola secara optimal oleh masyarakat dengan pengelolaan yang baik untuk mencapai keberhasilan hidup, sehingga masih banyak dijumpai penduduk yang kekurangan pangan dan gizi, protein kalori dan lain sebagainya terutama di daerah terpencil (Simanjuntak, 2006).

Kenyataan ini sangat erat hubungannya dengan rata rata tingkat pendidikan yang masih rendah. Permasalahan ini juga tidak lepas minimnya luas kepemilikan sawah dengan rata rata $0,5 \mathrm{Ha}$. Sehingga dampak yang diberikan adalah rendahnya penerimaan atas usahatani yang yang dikelola. Karena secara rasional dapat diuraikan, tingkat pendapatan yang diterima oleh petani dipengaruhi oleh produksi dan jumlah biaya yang digunakan. Sementara hasil atau produksi lebih banyak ditentukan oleh luas lahan.

Bertitik tolak dari uraian tersebut, maka sangat urgen untuk dilakukan penelitian yang berkaitan dengan hubungan antara luas lahan dan tingkat pendidikan dengan peningkatan pendapatan usahatani padi.

\section{TUJUAN PENELITIAN}

Penelitian ini bertujuan antara lain, untuk :

1. Mengetahui hubungan antara luas luas lahan dengan peningkatan pendapatan usahatani padi

2. Mengetahui hubungan antara tingkat pendidikan dengan peningkatan pendapatan usahatani padi

\section{ANALISIS DATA}

Setelah data dikumpulkan, selanjutnya dianalisis dengan menggunakan rumus Menurut Sujana (1992) sebagai berikut:

Pengujian Hipotesis :

$$
\hat{Y}=a+b x
$$

Dimana :

$\hat{\mathrm{Y}} \quad=$ Tingkat Pendapatan $(\mathrm{Rp})$ 


$$
\begin{aligned}
\mathrm{a} & =\text { Konstanta } \\
\mathrm{b} & =\text { Koefisien regresi } \\
\mathrm{X} & =\text { Luas lahan }(\mathrm{Ha}) / \text { Tingkat } \\
& \text { Pendidikan }
\end{aligned}
$$
adalah:

Adapun langkah yang ditempuh

a. Mencari nilai parameter a dan b dengan menggunakan persamaan sebagai berikut:

$$
\begin{gathered}
a=\frac{\sum \mathrm{Y}-\mathrm{b} \sum \mathrm{X}}{\mathrm{n}} \\
b=\frac{\mathrm{n} \sum \mathrm{XY}-\sum \mathrm{X} \cdot \sum \mathrm{Y}}{\mathrm{n} \sum \mathrm{X}^{2}-\left(\sum \mathrm{X}\right)^{2}}
\end{gathered}
$$

Dimana :

$\mathrm{n}=$ sampel

b. Analisis Korelasi untuk mengetahui hubungan antara variabel

$$
r=\frac{\mathrm{n} \sum \mathrm{XY}-\sum \mathrm{X} \cdot \sum \mathrm{Y}}{\sqrt{\sum \mathrm{X}^{2}-\left(\sum \mathrm{X}\right)^{2}} \sqrt{\sum \mathrm{Y}^{2}-\left(\sum \mathrm{Y}\right)^{2}}}
$$

\section{HASIL DAN PEMBAHASAN}

\section{Analisis Pendapatan}

Berdasarkan hasil olahan kuisioner,

\begin{tabular}{|c|c|c|c|}
\hline No & Uraian & Total Nilai (Rp) & Nilai Per Ha (Rp) \\
\hline 1 & $\begin{array}{l}\text { Penerimaan } \\
\text { a. Produksi } \\
\text { b. Harga Produksi }\end{array}$ & $96,800,000$ & $3,520,000$ \\
\hline 2 & 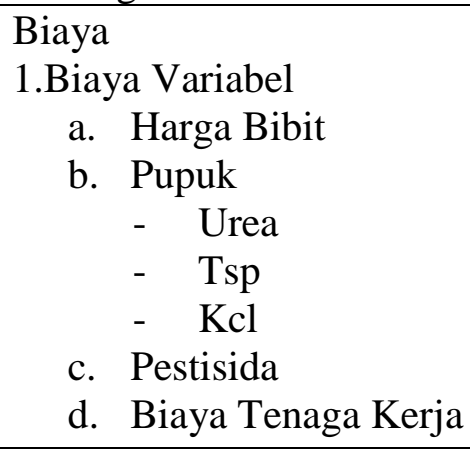 & $\begin{array}{r}4,620,000 \\
4,743,750 \\
8,250,000 \\
3,643,750 \\
935,000 \\
27,337,500 \\
\end{array}$ & $\begin{array}{r}168.000 \\
172,500 \\
300,000 \\
132,500 \\
34,000 \\
994,091 \\
\end{array}$ \\
\hline & Jumlah (BV) & $49,530,000$ & $1,801,091$ \\
\hline & $\begin{array}{l}\text { 2. Biaya Tetap } \\
\text { a. Penyusutan alat } \\
\text { b. Pajak }\end{array}$ & $\begin{array}{r}250,250 \\
6,310,000\end{array}$ & $\begin{array}{r}9,100 \\
229,455\end{array}$ \\
\hline & $\begin{array}{l}\text { Jumlah (BT) } \\
\text { Jumlah (BV + BT) }\end{array}$ & $\begin{array}{r}6,560,250 \\
56,090,250\end{array}$ & $\begin{array}{r}238,555 \\
2,039,645 \\
\end{array}$ \\
\hline
\end{tabular}
maka rata-rata Produksi, penerimaan dan total biaya yang harus dikeluarkan oleh petani dapat dilihat pada tabel di bawah ini:

Tabel 1 Rata-rata Produksi, Penerimaan dan Biaya Usahatani Padi tiap hektar di Desa Topore Kecamatan Papalang

Sumber Data Primer setelah diolah, 2017

Berdasarkan tabel di atas terlihat bahwa Total penerimaan responden di Desa Topore sebesar Rp. 96,800,000, sedangkan rata-rata penerimaan setiap hektar sebesar Rp. 3,520,000.

Sedangkan rata-rata biaya variable yang harus dikeluarkan responden sebesar Rp. $1,801,091$ dan rata-rata biaya tetap sebesar Rp. 238,555. Sehingga total 
biaya yang harus dikeluakan dalam usahatani padi sebesar Rp. 2,039,645.

Selanjutnya untuk mengetahui ratarata pendapatan yang diterima dalam satu musim tanam, dapat dilihat pada rumus berikut:

$$
\begin{aligned}
\mathrm{Pd} & =\mathrm{TR}-\mathrm{TC} \\
& =\text { Rp. } 3,520,000-\text { Rp. } 2,039,645 \\
& =\text { Rp. } 1,480,355
\end{aligned}
$$

Hal ini mengindikasikan bahwa rata-rata pendapatan yang diterima oleh petani responden di dalam usahatani padi sangat tinggi. Hal berarti keuntungan yang diterima petani dalam usahatani padi sangat tinggi.

2. Analisis Hubungan Luas Lahan dengan Pendapatan

Hubungan yang dimaksud dalam hal ini adalah tingkat hubungan atau keterkaitan antara luas lahan dengan pendapatan di tingkat petani

Berdasarkan hasil analisis regresi linear, maka diperoleh hubungan antara luas lahan dengan pendapatan usahatani adalah sebagai berikut:

Gambar 1 Hubungan Antara Luas Lahan dengan Pendapatan di Desa Topore

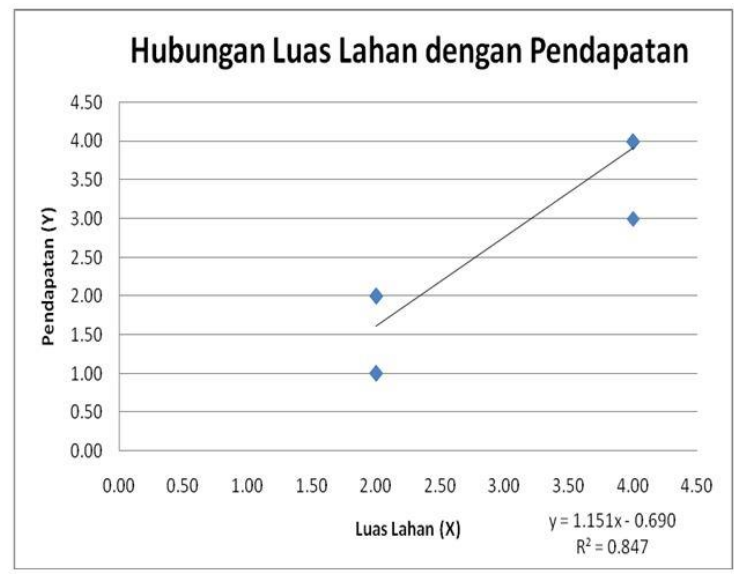

Gambar 1 di atas memperlihatkan bahwa antara luas lahan dengan pendapatan menunjukkan hubungan yang positif. Dimana makin luas lahan, maka akan menyebabkan peningkatan terhadap pendapatan usahatani padi sawah

$$
\mathrm{Y}=6377,2+39,449 \mathrm{x}
$$

Hasil di atas terlihat bahwa nilai koefisien regresi adalah 39,449 sedangkan konstanta 6377,2. Dengan demikian jika terjadi peningkatan luas lahan sebesar satu satuan, maka akan diikuti oleh penambahan pendapatan sebesar Rp. 39,449 dengan nilai konstan.

Hal ini menunjukkan bahwa luas lahan akan menimbulkan peningkatan pendapatan usahatani padi. Secara teoritis dapat dinyatakan bahwa jika luas lahan meningkat, maka pendapatan usahatani meningkat, Begitupula sebaliknya.

Sementara nilai koefisien korelasi (r) adalah sebesar 0.717409 ini berarti hubungan antara variabel tak bebas (y) dengan variabel bebas (x) menunjukkan hubungan linear sempurna yang langsung. Hal ini menunjukkan bahwa korelasi antara luas lahan dengan pendapatan relatif tinggi. Atau dengan kata lain luas lahan menunjukkan perubahan yang signifikan terhadap peningkatan pendapatan.

Hal ini sesuai dengan indikator menurut Subino dalam Subarna dan Sudrajat (2001), yaitu:

$\leq 0,20 \quad:$ tidak ada korelasi

$0,20-0,40 \quad$ : Korelasi rendah

$0,40-0,70 \quad$ : Korelasi Sedang

0,70-0,90 : Korelasi tinggi

0,90-1,00 : Korelasi sangat Tinggi

$1,00 \quad$ : Korelasi Sempurna

Berdasarkan indikator di atas, maka dapat dikatakan bahwa bahwa korelasi antara luas lahan dengan pendapatan usahatani padi adalah korelasi tinggi. Atau dengan kata lain luas lahan 
menunjukkan perubahan yang tidak signifikan terhadap pendapatan usahatani padi Di Desa Topore.

Koefisien determinasinya $\left(\mathrm{r}^{2}\right)$ sebesar 0, 847. dari hasil tersebut kemudian dihitung dengan menggunakan persamaan:

$$
\begin{aligned}
& \mathrm{KP}=\mathrm{r}^{2} \mathrm{x} 100 \% \\
& \mathrm{KP}=0,847 \times 100 \% \\
& \mathrm{KP}=84,7 \%
\end{aligned}
$$

Hasil tersebut memperlihatkan bahwa peningkatan pendapatan oleh luas lahan sebesar 84,7 \% berdasarkan persamaan di atas, sedangkan 15,3\% lainnya disebabkan oleh faktor-faktor lain.

\section{Analisis Hubungan Tingkat Pendidikan dengan Pendapata}

Berdasarkan hasil wawancara dengan menggunakan kuisioner terhadap responden yang ada di Desa Topore, maka diperoleh data mengenai tingkat pendidikan dan pendapatan. Kemudian dilakukan scoring untuk kemudian dianalisis regresi linear, maka diperoleh hubungan antara kulitas beras dengan harga penjualan seperti pada diagram pencar di bawah ini:

Gambar 2 Hubungan Antara Tingkat Pendidikan dengan Pendapatan di Desa Topore

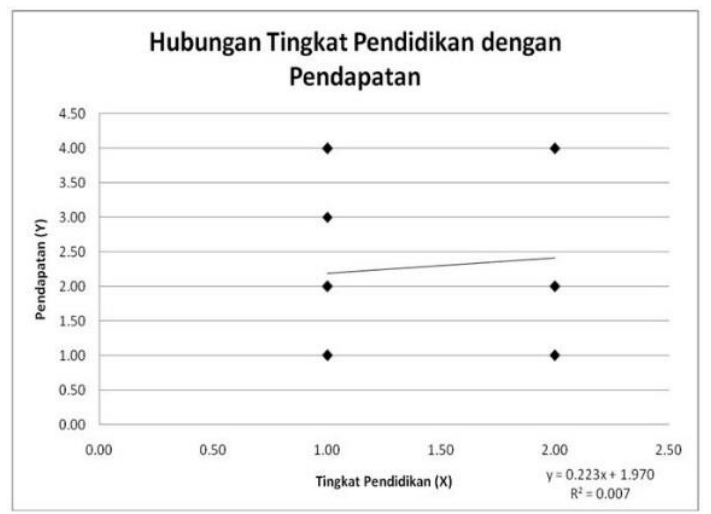

Gambar 2 di atas memperlihatkan bahwa antara tingkat pendidikan dengan pendapatan menunjukkan hubungan yang positif. Dimana makin tinggi tingkat pendidikan, maka akan menyebabkan peningkatan terhadap pendapatan usahatani padi sawah.

$$
Y=1.970+0.223 x
$$

Hasil di atas terlihat bahwa nilai koefisien regresi adalah 0.223 sedangkan konstanta 1.970. Dengan demikian jika terjadi peningkatan tingkat pendidikan sebesar satu satuan, maka akan diikuti oleh penambahan pendapatan sebesar Rp.1.970 dengan nilai konstan.

Hal ini menunjukkan bahwa tingkat pendidikan menimbulkan peningkatan pendapatan usahatani padi. Secara teoritis dapat dinyatakan bahwa jika tingkat pendidikan meningkat, maka pendapatan usahatani meningkat, Begitupula sebaliknya.

Sementara nilai koefisien korelasi (r) adalah sebesar 0.000049 ini berarti hubungan antara variabel tak bebas (y) dengan variabel bebas (x) menunjukkan hubungan linear sempurna yang langsung. Hal ini menunjukkan bahwa korelasi antara tingkat pendidikan dengan pendapatan relatif rendah. Atau dengan kata lain luas lahan menunjukkan perubahan yang tidak signifikan terhadap peningkatan pendapatan. Sedangkan berdasarkan indikator Subino dalam Subarna dan Sudrajat (2001) yang menyatakan jumlah $\mathrm{r}=0.000049$ berada pada interval di bawah 0,20 yang menunjukkan tidak ada korelasi.

Koefisien determinasinya $\left(\mathrm{r}^{2}\right)$ sebesar 0, 007. dari hasil tersebut kemudian dihitung dengan menggunakan persamaan.

$$
\begin{aligned}
& \mathrm{KP}=\mathrm{r}^{2} \times 100 \% \\
& \mathrm{KP}=0,007 \times 100 \% \\
& \mathrm{KP}=0,70 \%
\end{aligned}
$$


Hasil tersebut memperlihatkan bahwa peningkatan pendapatan oleh tingkat pendidikan hanya sebesar $0,7 \%$ berdasarkan persamaan di atas. Ini berarti bahwa peningkatan pendapatan dominan dipengaruhi oleh faktor lain.

\section{KESIMPULAN}

Berdasarkan pada hasil pembahasan tersebut, maka dapat diperoleh kesimpulan seabagai berikut : 1) Luas lahan berpengaruh secara signifikan terhadap peningkatan pendapatan usahatani padi yaitu sebesar 84,7 persen, dan 2) Tingkat pendidikan tidak berpengaruh secara signifikan terhadap peningkatan pendapatan usahatani padi yaitu hanya sebesar 0,7 persen.

\section{DAFTAR PUSTAKA}

Arsyad, L. (2014). Ekonomi Pembangunan.
Elizabeth, R. (2016). Fenomena Sosiologis Metamorphosis Petani: Ke arah Keberpihakan Pada Masyarakat Petani di Pedesaan yang Terpinggirkan Terkait Konsep Ekonomi kerakyatan. In Forum Penelitian Agro Ekonomi (Vol. 25, pp. 2942).

Rosegrant, M. W., Kasryno, F., Gonzales, L. A., Rasahan, C., \& Saefudin, Y. (1987). Price and Investment Policies in the Indonesian Food Crop Sector.

Simanjuntak, D. (2006). Pemanfaatan Komoditas Non Beras dalam Diversifikasi Pangan Sumber Kalori. Pemanfaatan Komoditas Non Beras Dalam Diversifikasi Pangan Sumber Kalori.

Sujana, T. (1992). Metode Statistik, Edisi ke 5. Tarsito. 